\title{
Detecção Molecular de Xylella fastidiosa em Citros no Estado do Pará
}

\author{
Luiz S. Poltronieri' ${ }^{1}$, Jadier O. Cunha Junior ${ }^{2}$, Dinaldo R. Trindade ${ }^{1}$, Shirley S. Cardoso ${ }^{3}$ \& Paulo S.T. Brioso ${ }^{2}$ \\ ${ }^{1}$ Embrapa Amazônia Oriental, Tv. Dr. Enéas Pinheiro, s/no ${ }^{\circ}$ CEP 66095-100, Belém, PA, e-mail: poltroni@cpatu.embrapa.br, \\ ${ }^{2}$ Laboratório de Virologia e Viroides/DENF/IB/UFRRJ, Cx. Postal 74585, Seropédica, RJ, CEP 23651-970, \\ ${ }^{1}$ Universaidade Federal Rural da Amazônia, Av. Perimetral, 2501, Belém, PA
}

(Aceito para publicação em 14/10/2004)

Autor para correspondência: Luiz S. Poltronieri

\begin{abstract}
Molecular Detection of Xylella fastidiosa in citrus in the state of Para, Brazil

This paper reports the occurrence of chlorosis variegation of citrus (Citrus spp.) in the state of Para, Brazil. The presence of the pathogen was detected by PCR in extracts of total DNA from leaf petioles using specific primes to Xylella fastidiosa.
\end{abstract}

A cultura do citros (Citrus spp.) no Estado do Pará se destaca com uma área em torno de 15 mil ha, sendo uma cultura em expansão, com produção da ordem de 1.508.139 ton, para um rendimento médio de 300 frutos/plantas. A produção concentra-se, principalmente, na microrregião do Guamá, onde os municípios de Capitão Poço, Garrafão do Norte, Irituia e Ourém constituem o chamado pólo cítricola. Recentemente, foram coletadas nos municípios paraenses de Igarapé-Mirim, Ourém e Capitão Poço, folhas e frutos de laranjeira 'Pêra' (Citrus sinensis Osbeck) com sintomas semelhantes à clorosoe variegada dos citros (CVC). Objetivando a confirmação molecular da presença do patógeno, as amostras coletadas foram encaminhadas ao laboratório de virologia da Universidade Federal Rural do Rio de Janeiro e submetidas ao teste de PCR com "primers" específicos para Xylella fastidiosa Wells, usando folhas sadias como controle negativo. A extração foi realizada a partir de $250 \mathrm{mg}$ de pecíolo com $\mathrm{N}_{2}$ líquido e homogeneizado com tampão CTAB sarcosyl. Os primes utilizados para a amplificação, bem como o programa do termociclador, foram os descritos por Pooler \& Harttung (Current Microbiol 31:377-381. 1995). A reação foi composta por $5 \mu 1$ do DNA da amostra, $0,3 \mu 1$ da Taq polimerase, $0,5 \mu 1$ de cada "primer", $1 \mu 1$ de dNTPs., $2,5 \mu 1$ tampão $10 \mathrm{X}$ e completado a $25 \mu \mathrm{l}$ com água. Os produtos foram visualizados em transiluminador de luz ultravioleta após eletroforese em gel de agarose $1 \%$ corado com brometo de etídio. $O$ resultado evidenciou a amplificação de um fragmento majoritário de, aproximadamente, $500 \mathrm{pb}$ somente na amostra da planta sintomática (Figura 1). Em citros, essa bactéria já foi relatada nos Estados de Goiás, Minas Gerais, Paraná, Rio de Janeiro, Rio Grande do Sul, Santa Catarina,
Sergipe, São Paulo e no Distrito Federal. A doença foi anteriormente assinalada no Estado do Pará através da sintomatologia, sendo a presença do fitopatógeno confirmada molecularmente neste trabalho. A detecção molecular desta bactéria permite agilizar e implantar um futuro programa de controle do CVC. Este é provavelmente o primeiro relato da ocorrência de $X$. fastidiosa em citros no Estado do Pará.

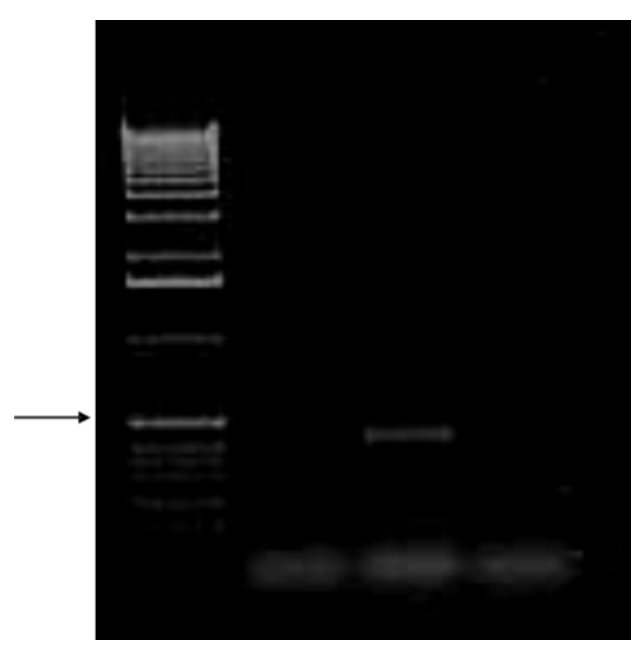

FIG. 1 - Eletroforese em gel de agarosea 1\%, corado com brometo de etídio, dos produtos de PCR a partir do DNA total do pecíolo de laranjeira 'Pêra' (Citrus sinensis). (L) 1 Kb DNA "Ladder"; (1) controle negativo 'Pêra' - Seropédica, RJ; (2) laranja 'Pêra' sintomática do estado do Pará; (3) produto de PCR sem DNA molde, controle negativo. 